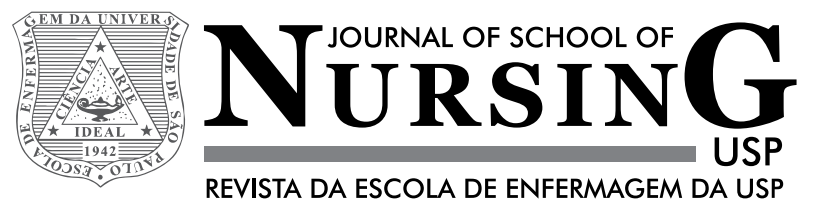

\title{
Knowledge of the Portuguese population on Basic Life Support and availability to attend training
}

\section{Conhecimento da população portuguesa sobre suporte básico de vida e disponibilidade para realizar formação \\ Conocimiento de la población portuguesa acerca del soporte básico de vida y disponibilidad para realizar formación}

\section{Maria dos Anjos Coelho Rodrigues Dixe ${ }^{1}$, José Carlos Rodrigues Gomes ${ }^{1}$}

\footnotetext{
${ }^{1}$ Instituto Politécnico de Leiria, Escola Superior de Saúde de Leiria, Unidade de Investigação em Saúde, Leiria, Portugal.
}

\section{ABSTRACT}

Objective: To evaluate the level of knowledge and the availability of the Portuguese population to attend training in Basic Life Support (BLS) and identify factors related to their level of knowledge about BLS. Method: Observational study including 1,700 people who responded to a questionnaire containing data on demography, profession, training, interest in training and knowledge about BLS. Results: Among 754 men and 943 women, only $17.8 \%$ (303) attended a course on BLS, but $95.6 \%$ expressed willingness to carry out the training. On average, they did not show good levels of knowledge on basic life support (correct answers in $25.9 \pm 11.5$ of the 64 indicators). Male, older respondents who had the training and those who performed BLS gave more correct answers, on average $(\mathrm{p}<0.01)$. Conclusion: The skill levels of the Portuguese population are low, but people are available for training, hence it is important to develop training courses and practice to improve their knowledge.

\section{DESCRIPTORS}

Cardiopulmonary Resuscitation; First Aid; Knowledge; Health Education. 


\section{INTRODUCTION}

A medical emergency is the health sector activity comprising all the events happening from where an emergency situation takes place, until the moment of its conclusion with restoration of an adequate health level ${ }^{(1-2)}$. In Portugal, those involved in the emergency medical integrated system are: the public, the emergency center operators (emergency number 112), the technicians of the emergency patients guidance center (CODU - Centro de Orientação de Doentes Urgentes), law enforcement officers, firefighters, ambulance crews, emergency ambulance technicians, doctors and nurses, technical and hospital staff, telecommunications and informatics technical staff ${ }^{(1)}$.

Saving lives involves a sequence of steps that constitute the chain of survival, with four steps, namely: early access to integrated medical emergency; early initiation of basic life support (BLS); early defibrillation and advanced life support (ALS) $)^{(1-2)}$

The BLS under citizen responsibility ${ }^{(1)}$ is a well-defined set of procedures with standardized methodologies and the following objectives: recognize life threatening situations; know when and how to ask for help; have the ability to start immediately and without aid of any equipment, maneuvers to preserve oxygenation and circulation until the arrival of specific teams and eventually, the restoration of normal cardiac and respiratory function ${ }^{(1-2)}$.

The prevalence of accidents in Portugal has caused victims at home, at work and on public spaces, being a current health problem that reflects the way of life and the organization of spaces and society. In 2011, there were 32,541 road accidents in Portugal resulting in 42,851 casualties. The fatalities (30 day-period) amounted to $891^{(3)}$.

Ischemic heart disease is the leading cause of death worldwide. In Europe and the US, ischemic heart disease is the leading cause of sudden cardiac arrest ${ }^{(1-2)}$. About a third of victims of acute myocardial infarction die before reaching the hospital, most within an hour of the symptoms onset. Data from various European countries show the annual incidence of cardiac arrest in the prehospital system is almost 40 per $100,000^{(1-2)}$.

Sudden cardiac arrest is about $11 \%$ of deaths per year in Germany ${ }^{(4)}$. In this and other emergencies, a rapid intervention would save people and prevent complications. About 50 to $65 \%$ of cardiac arrests occur at home. In such cases, family members who are close have the power to intervene. Many of these people would be saved if they were rescued in the first 3-4 minutes after the critical event ${ }^{(1-2,4)}$. Given this fact, many authors stress the importance of including first aid training in school curricula ${ }^{(5-8)}$.

To provide proper care, people need sufficient and adequate knowledge on BLS, which sometimes does not happen, requiring training ${ }^{(8-9)}$ either in person or online ${ }^{(10-11)}$. If the latter is of quality ${ }^{(12)}$, it can favor the increased number of trained people by reducing the need to travel to attend courses.

Given the above and the potential value of first aid training as a strategic element to reduce mortality and morbidity caused by accidents and emergencies ${ }^{(11)}$, this study aimed to: assess the knowledge level on BLS of the Portuguese population; know their willingness to carry out training in BLS and identify some factors (age, gender, frequency to a BLS course and previous experience in BLS) related to the level of knowledge about BLS.

\section{METHOD}

We conducted an observational descriptive and correlated study. The population comprised Portuguese residents in continental Portugal, the Azores and Madeira islands, aged 18 years or over, able to read and write and who where working in public and private institutions. The selection of data collection sites and sample was conducted as follows:

a) We made a list of all public and private institutions to which we had access in the yellow pages;

b) Two public or private institutions in each city of Portugal, including the islands of Azores and Madeira were selected by lot;

c) The study protocol and its respective applications for authorization were submitted to the board of directors and ethics committee of the chosen institutions;

d) After authorizations were granted, the employees of each institution in charge of instruments application were defined. They were sent instructions for data collection;

e) The instruments were applied to respondents in a room chosen for this purpose, before the start or in the end of the work activity.

f) After filling out the questionnaires, respondents put them in a ballet box in the room to maintain anonymity;

g) The employees returned the completed questionnaires to researchers by mail.

The non-probabilistic sample consisted of 1,700 respondents of both genders (55.6\% women and $44.4 \%$ men), mean age of 37.7 years $(\mathrm{SD}=10.5)$, who exercised functions in 250 of the 318 institutions selected (participation rate of $78.6 \%)$. below:

The applied instrument contained three parts, described

Sociodemographic and professional data: residence; age; gender; marital status; educational level and profession.

Training and interest in BLS training: frequency to any BLS course; experience in performing BLS; any citizen can help a victim in life-threatening situation: who should have knowledge about BLS; opinion about beginning BLS training in a teaching program; BLS training in the workplace; BLS training in associations; BLS training providers; interest in receiving BLS training; willingness to undertake BLS training and previous experience of volunteering or in health institutions.

BLS knowledge: 64 affirmations based on orientation defined in national and international guidelines for this article ${ }^{(1-2,13)}$. The correct answers received the score 1 , and wrong answers received the score 0 (zero). Thus, the total score ranged from 0-64 points. For content validation, the instrument was appreciated by field experts (doctors and nurses), and a pretest was applied to 20 people with the same characteristics of the target population. There was no need to make changes. 
The study protocol was approved by all the ethics committees of the institutions. In institutions where there was no ethics committee (180 institutions), the protocol was approved by their administration boards. Before the application of instruments, the study objectives and purposes were explained for all the subjects. Before completing, all participants signed the informed consent form.

The SPSS (Statistical Package for the Social Sciences), version 17 , and descriptive and inferential statistics were used. Since the variable of level of knowledge about basic life support presented normal distribution (Kolmogorov-Smirnov), we used the Pearson correlation and the $t$ Student test, establishing a significance level of $95 \%$ with $\mathrm{p}<0.05$.

\section{RESULTS}

\section{SOCIODEMOGRAPHIC AND PROFESSIONAL}

\section{CHARACTERISTICS OF THE SAMPLE}

More than half of the respondents were female (55.6\%), married $(60.7 \%)$ with mean age of $37.7 \pm 10.5$ years. The education of the majority (65.1\%) was until $12^{\text {th }}$ grade or higher education, and $30.2 \%$ of respondents were administrative staff or similar (Table 1).

Table 1 - Distribution of the sample answers regarding sociodemographic and professional characteristics - Portugal, 2010-2012.

\begin{tabular}{|c|c|c|c|}
\hline Variables & & $\mathbf{N}^{\circ}$ & $\%$ \\
\hline \multirow{2}{*}{$\begin{array}{l}\text { Gender } \\
(\mathrm{n}=1,697)\end{array}$} & Male & 754 & 44.4 \\
\hline & Female & 943 & 55.6 \\
\hline \multirow{4}{*}{$\begin{array}{l}\text { Marital status } \\
(\mathrm{n}=1,690)\end{array}$} & Married & 1025 & 60.7 \\
\hline & Divorced & 190 & 11.2 \\
\hline & Single & 461 & 27.3 \\
\hline & Widowed & 14 & 0.8 \\
\hline \multirow{4}{*}{$\begin{array}{l}\text { Educational } \\
\text { level } \\
(n=1,690)\end{array}$} & $\begin{array}{l}\text { Incomplete primary } \\
\text { Complete primary }\end{array}$ & $\begin{array}{c}13 \\
175\end{array}$ & $\begin{array}{c}0.8 \\
10.4\end{array}$ \\
\hline & $\begin{array}{l}6^{\text {th }} \text { grade } \\
9^{\text {th }} \text { grade }\end{array}$ & $\begin{array}{l}112 \\
289\end{array}$ & $\begin{array}{c}6.6 \\
17.1\end{array}$ \\
\hline & $12^{\text {th }}$ grade & 572 & 33.8 \\
\hline & Higher education & 529 & 31.3 \\
\hline \multirow{7}{*}{$\begin{array}{l}\text { Profession } \\
(1,644)\end{array}$} & $\begin{array}{l}\text { Members of the armed } \\
\text { forces }\end{array}$ & 6 & 0.4 \\
\hline & $\begin{array}{l}\text { Senior management of } \\
\text { public administration }\end{array}$ & 20 & 1.2 \\
\hline & $\begin{array}{l}\text { Specialist in intel- } \\
\text { lectual and scientific } \\
\text { professions }\end{array}$ & 380 & 23.1 \\
\hline & $\begin{array}{l}\text { Technicians and } \\
\text { intermediate level } \\
\text { professionals }\end{array}$ & 214 & 13.0 \\
\hline & $\begin{array}{l}\text { Administrative staff } \\
\text { and alike }\end{array}$ & 497 & 30.2 \\
\hline & $\begin{array}{l}\text { Services and sales } \\
\text { personel }\end{array}$ & 171 & 10.4 \\
\hline & $\begin{array}{l}\text { Agricultural and fish- } \\
\text { ery skilled workers }\end{array}$ & 18 & 1.1 \\
\hline
\end{tabular}

\begin{tabular}{llcc} 
V...continuation & & & \\
\hline Variables & & $\mathbf{N}^{\mathbf{o}}$ & $\%$ \\
\hline & $\begin{array}{l}\text { Factory workers, craft } \\
\text { and related trades } \\
\text { workers }\end{array}$ & 69 & 4.2 \\
& $\begin{array}{l}\text { Plant and machine } \\
\text { operators }\end{array}$ & 40 & 2.4 \\
$\begin{array}{l}\text { Profession } \\
(1,644)\end{array}$ & Unskilled worker & 113 & 6.9 \\
& $\begin{array}{l}\text { Student, working } \\
\text { student }\end{array}$ & 83 & 5.0 \\
& Retired & 15 & 0.9 \\
& Unemployed & 15 & 0.9 \\
& Military & 3 & 0.2 \\
\hline
\end{tabular}

\section{Training and experience of the Portuguese POPULATION IN BASIC LIFE SUPPORT}

Only 303 (17.8\%) had attended a BLS course, the majority in the Portuguese Red Cross (23.5\%) or qualified training centers (21.8\%); $14.6 \%$ needed to perform BLS, with traffic accident $(22.5 \%)$ as the most cited situation. The intervention carried out more times (47.5\%) was calling 112 (Table 2).

Table 2 - Distribution of the sample answers in relation to training and experience in BLS - Portugal, 2010-2012.

\begin{tabular}{|c|c|c|}
\hline Training and experience in BLS & $\mathbf{N}^{\mathbf{o}}$ & $\%$ \\
\hline \multicolumn{3}{|l|}{ Frequency of BLS course $(n=1,700)$} \\
\hline Yes & 302 & 17.8 \\
\hline No & 1.398 & 82.2 \\
\hline \multicolumn{3}{|l|}{ Training Institution $(n=293)$} \\
\hline University/Higher Education Institution & 49 & 16.7 \\
\hline Hospital/Health Centers & 6 & 2.0 \\
\hline Qualified Training Centers & 64 & 21.8 \\
\hline Portuguese Red Cross & 69 & 23.5 \\
\hline $\begin{array}{l}\text { National Institute of Medical Emergency } \\
\text { (INEM) }\end{array}$ & 7 & 2.4 \\
\hline Firefighters & 48 & 16.4 \\
\hline Military Institution & 11 & 3.8 \\
\hline At work & 16 & 5.5 \\
\hline Secondary school & 7 & 2.4 \\
\hline Guides Association Portugal & 1 & 0.3 \\
\hline Scouts & 4 & 1.4 \\
\hline Portuguese Gymnastics Federation & 1 & 0.3 \\
\hline City Council & 10 & 3.4 \\
\hline \multicolumn{3}{|l|}{ Have you ever had to perform BLS $(n=1,668)$} \\
\hline Yes & 243 & 14.6 \\
\hline No & 1.425 & 85.4 \\
\hline \multicolumn{3}{|l|}{ Situations in which you performed BLS $(n=405)$} \\
\hline Drowning & 30 & 7.4 \\
\hline Traffic accident & 91 & 22.5 \\
\hline Choking & 41 & 10.1 \\
\hline Heart attack & 47 & 11.6 \\
\hline Cerebrovascular accident (CVA) & 48 & 11.9 \\
\hline Situations in which you performed BLS $(n=405$ & & \\
\hline
\end{tabular}




\begin{tabular}{|c|c|c|}
\hline \multicolumn{3}{|l|}{...continuation } \\
\hline Training and experience in BLS & $\mathbf{N}^{\mathbf{o}}$ & $\%$ \\
\hline Burn & 38 & 9.4 \\
\hline Intoxication and/or Food poisoning & 28 & 6.9 \\
\hline Electrocution & 11 & 2.7 \\
\hline Other situations & 71 & 17.5 \\
\hline \multicolumn{3}{|l|}{ Activity performed ( $n=238$ references) } \\
\hline Called Firefighters & 38 & 16 \\
\hline Called the Police & 6 & 2.5 \\
\hline Called 112 & 113 & 47.5 \\
\hline Asked for help & 10 & 4.2 \\
\hline Performed activity on the victim & 71 & 29.8 \\
\hline \multicolumn{3}{|l|}{ Activity performed on the victim $(n=100)$} \\
\hline Raised legs & 13 & 13.0 \\
\hline Lie on the floor & 21 & 21.0 \\
\hline Stanched bleeding & 3 & 3.0 \\
\hline Put water on the affected limb & 1 & 1.0 \\
\hline Back blow & 9 & 9.0 \\
\hline First aid & 30 & 30.0 \\
\hline Kept the victim conscious & 1 & 1.0 \\
\hline Rescued the victim & 5 & 5.0 \\
\hline Placed victim in the Recovery Position & 5 & 5.0 \\
\hline Cardiac massage and ventilation & 5 & 5.0 \\
\hline BLS application & 6 & 6.0 \\
\hline Heimlich manouver & 1 & 1.0 \\
\hline
\end{tabular}

According to $54.1 \%$ of the participants, any citizen can help a victim and, therefore, must have knowledge on BLS (81.4\%). They also indicated that training should be done in the workplace (84.9\%). The National Institute of Medical Emergency (63.6\%) and the Firefighters (62.1\%) were the most cited to conduct training in BLS (Table 3).

Table 3 - Distribution of the sample answers regarding the opinion about who should attend BLS training and where - Portugal, 2010-2012.

\begin{tabular}{lcccc}
\hline \multirow{2}{*}{$\begin{array}{l}\text { Who should attend BLS training } \\
\text { and where? }\end{array}$} & \multicolumn{2}{c}{ Yes } & \multicolumn{2}{c}{ No } \\
\cline { 2 - 5 } & $\mathbf{N}^{\mathbf{0}}$ & $\%$ & $\mathbf{N}^{\mathbf{0}}$ & $\%$ \\
\hline $\begin{array}{l}\text { Any citizen can help a victim in } \\
\text { life-threatening situation }\end{array}$ & 857 & 54.1 & 728 & 45.9 \\
$\begin{array}{l}\text { All citizens should have knowl- } \\
\text { edge on BLS }\end{array}$ & 1,320 & 81.4 & 301 & 18.6 \\
$\begin{array}{l}\text { Teachers should have knowl- } \\
\text { edge on BLS }\end{array}$ & 249 & 15.4 & 1,372 & 84.6 \\
$\begin{array}{l}\text { Firefighters should have knowl- } \\
\text { edge on BLS }\end{array}$ & 461 & 28.4 & 1,160 & 71.6 \\
$\begin{array}{l}\text { Health professionals should } \\
\text { have knowledge on BLS }\end{array}$ & 436 & 26.9 & 1,185 & 73.1 \\
$\begin{array}{l}\text { In addition to the aforemen- } \\
\text { tioned, others should have } \\
\text { knowledge on BLS }\end{array}$ & 79 & 4.9 & 1,542 & 95.1 \\
$\begin{array}{l}\text { The military should have knowl- } \\
\text { edge on BLS }\end{array}$ & 263 & 16.2 & 1,358 & 83.8 \\
$\begin{array}{l}\text { Police should have knowledge } \\
\text { on BLS }\end{array}$ & 297 & 18.4 & 1,317 & 81.6 \\
\hline
\end{tabular}

continued... ...continuation

\begin{tabular}{|c|c|c|c|c|}
\hline \multirow{2}{*}{$\begin{array}{l}\text { Who should attend BLS training } \\
\text { and where? }\end{array}$} & \multicolumn{2}{|c|}{ Yes } & \multicolumn{2}{|c|}{ No } \\
\hline & $\mathbf{N}^{0}$ & $\%$ & $\mathrm{~N}^{\circ}$ & $\%$ \\
\hline $\begin{array}{l}\text { BLS training should be done in } \\
\text { the workplace }\end{array}$ & 1,436 & 84.9 & 256 & 15.1 \\
\hline $\begin{array}{l}\text { BLS training should be done } \\
\text { in cultural and recreational as- } \\
\text { sociations, aimed at community } \\
\text { groups }\end{array}$ & 1,446 & 88.4 & 189 & 11.6 \\
\hline $\begin{array}{l}\text { BLS training should be given by } \\
\text { the National Institute of Medical } \\
\text { Emergency }\end{array}$ & 1,048 & 63.6 & 599 & 36.4 \\
\hline $\begin{array}{l}\text { BLS training should be given by } \\
\text { the Ministry of Health }\end{array}$ & 823 & 50.0 & 824 & 50.0 \\
\hline $\begin{array}{l}\text { BLS training should be given } \\
\text { by the Portuguese Resuscitation } \\
\text { Council }\end{array}$ & 187 & 11.4 & 1,459 & 88.6 \\
\hline $\begin{array}{l}\text { BLS training should be given by } \\
\text { the Red Cross }\end{array}$ & 814 & 49.4 & 834 & 50.6 \\
\hline $\begin{array}{l}\text { BLS training should be given by } \\
\text { the Firefighters }\end{array}$ & 1,024 & 62.1 & 624 & 37.9 \\
\hline $\begin{array}{l}\text { BLS training should be given by } \\
\text { the Civil Protection }\end{array}$ & 578 & 35.1 & 1,068 & 64.9 \\
\hline $\begin{array}{l}\text { BLS training should be given by } \\
\text { Schools }\end{array}$ & 783 & 47.5 & 866 & 52.5 \\
\hline
\end{tabular}

Among the respondents, 522 (30.9\%) emphasized that training in BLS should be initiated in the $2^{\text {nd }}$ grade; 482 $(29.8 \%)$ in the $1^{\text {st }}$ grade, $502(28.6 \%)$ in the $3^{\text {rd }}$ grade, 155 (9.8\%) in secondary school, and $13(0.8 \%)$ mentioned it should be integrated into higher education $(0.4 \%)$, with equal percentage mentioning that BLS training is not necessary $(0.4 \%)$. Regarding availability to attend a training, 655 (38.6\%) said they had plenty of availability, 378 (22.2\%) said they were available, $592(34.8 \%)$ reported being a bit available, and 75 (4.4\%) have not expressed any availability.

\section{KNOWLEDGE OF THE POPULATION ABOUT BASIC LIFE SUPPORT}

Before a breathing victim, more than $90 \%$ of respondents would ask someone to call 112 (Portuguese Medical Emergency number). More than half of respondents gave correct answers for several indicators, among which: before approaching a victim, one should evaluate the security situation (79.9\%); in a situation of electrocution, the rescuer must ensure that the power source was turned off before approaching the victim (79.6\%); ensure there are safe conditions for approaching the victim (79\%); try to see, hear and feel if the victim breathes for 10 seconds (77.9\%).

Among the 64 indicators, participants have given correct answers for $25.9 \pm 11.5$ on average, which is less than half of the proposed indicators. The level of knowledge on BLS $(r=0.98 ; p<0.01)$ increased as the respondents' age increased. On average, male participants who already had the training and those who had performed BLS hit more questions than female participants who did not have the training nor have performed BLS $(\mathrm{p}<001)$, as shown in Table 5 . 
Table 4 - Distribution of the sample answers about knowledge on BLS - Portugal, 2010-2012.

Areas Indicators
Faced with a seemingly unresponsive victim:

\begin{tabular}{crrr}
\multicolumn{2}{c}{ Wrong } & \multicolumn{2}{c}{ Correct } \\
\hline N & $\%$ & $\mathrm{~N}$ & $\%$ \\
\hline
\end{tabular}

Try to approach, even if exposed to danger

Ensure you have safe conditions to approach the victim

Check if the victim is responding to stimuli or not (tapping the shoulder and asking if the person is ok)

684

Stimulate the victim by shaking his/her head

In case the victim does not respond to stimulation:

Place a coat under the victim's head to avoid injuries on the floor

Scream for help

Give water with sugar

Check if there is any object inside the mouth

To continue a proper operation one must:

Place the victim on the side to avoid choking

Do extension of the head and/or chin lift

Try to look, listen and feel for breathing during 10 seconds

Put a hard object in the mouth to avoid biting the tongue

\section{If the victim is breathing:}

If not a polytrauma, position the victim on the side

Find signs of circulation

Ask somebody to call 112

Even if you are alone, do not leave the victim

If the victim is not breathing, coughing and there is no movement:

Ask somebody to call 112

Give four strong thrusts on the victim's chest to stimulate breathing

If you are alone, leave the victim and go ask for help

Put victim on the side

Start chest compression immediately

After checking the victim is not breathing and asking for help, one must:

Blow into the victim's mouth, checking if the chest moves

Wait for the arrival of specialized help

Observe the victim's mouth again, in case the blow has not been effective

Start chest compressions

Pinch the victim's nostrils with thumb and index finger

\section{When performing chest compressions:}

Do chest compressions with the victim's arms straight

Place the victim on the side

Start chest compressions at a rate of 50 per minute

Compress the chest the largest number of times possible

High count the number of chest compressions performed

When performing cardiopulmonary resuscitation one should:

Keep silent to avoid getting distracted when counting chest compressions

Alternate 30 chest compressions with two effective breaths

Know how long the victim has being revived

Keep BLS until arrival of specialized aid or the victim recovers signs of circulation

Alternate 15 chest compressions with two effective breaths (15:2)

Suspend CPR when feeling exhausted

360

$\begin{array}{llll}360 & 21.0 & 1,353 \quad 79.0\end{array}$

$501 \quad 29.2 \quad 1,212 \quad 70.8$

$\begin{array}{llll}381 & 22.2 & 1,332 & 77.8\end{array}$

$991 \quad 57.9 \quad 722 \quad 42.1$

$\begin{array}{llll}522 & 30.5 & 1.191 \quad 69.5\end{array}$

$\begin{array}{llll}703 & 41.0 & 1,010 & 59.0\end{array}$

$\begin{array}{llll}815 & 47.6 \quad 898 & 52.4\end{array}$

$\begin{array}{llll}1,430 & 83.5 & 283 & 16.5\end{array}$

$\begin{array}{llll}1,249 & 72.9 & 464 & 27.1\end{array}$

$\begin{array}{llll}378 & 22.1 & 1,335 & 77.9\end{array}$

$\begin{array}{llll}1,258 & 73.4 & 455 & 26.6\end{array}$

$833 \quad 48.6 \quad 880 \quad 51.4$

$\begin{array}{llll}1,548 & 90.4 & 165 & 9.6\end{array}$

$\begin{array}{llll}131 & 7.6 & 1,582 & 92.4\end{array}$

$\begin{array}{llll}1,569 & 91.6 & 144 & 8.4\end{array}$

$\begin{array}{llll}126 & 7.4 & 1,587 & 92.6\end{array}$

$\begin{array}{llll}956 & 55.8 & 757 & 44.2\end{array}$

$\begin{array}{llll}1,217 & 71.0 & 496 & 29.0\end{array}$

$1,241 \quad 72.4 \quad 472 \quad 27.6$

$\begin{array}{llll}1,034 & 60.4 & 679 & 39.6\end{array}$

$1,127 \quad 65.8 \quad 586 \quad 34.2$

$\begin{array}{llll}1,464 & 85.5 & 249 & 14.5\end{array}$

$\begin{array}{llll}1,437 & 83.9 & 276 & 16.1\end{array}$

$\begin{array}{llll}1,052 & 61.4 \quad 661 \quad 38.6\end{array}$

$\begin{array}{llll}1,431 & 83.5 & 282 & 16.5\end{array}$

$\begin{array}{llll}1,026 & 59.9 & 687 & 40.1\end{array}$

$\begin{array}{llll}978 & 57.1 & 735 & 42.9\end{array}$

$\begin{array}{llll}1,371 \quad 80.0 & 342 & 20.0\end{array}$

$\begin{array}{llll}1,203 & 70.2 & 510 & 29.8\end{array}$

$\begin{array}{llll}1,061 & 61.9 & 652 & 38.1\end{array}$

$\begin{array}{llll}1,398 & 81.6 & 315 & 18.4\end{array}$

$\begin{array}{llll}1,367 & 79.8 & 346 & 20.2\end{array}$

$\begin{array}{llll}1,529 & 89.3 & 184 & 10.7\end{array}$

$\begin{array}{llll}1,379 & 80.5 & 334 & 19.5\end{array}$

$908 \quad 53.0 \quad 805 \quad 47.0$

$\begin{array}{llll}1,480 & 86.4 & 233 & 13.6\end{array}$ 


\begin{tabular}{cccc}
\multicolumn{2}{c}{ Wrong } & \multicolumn{2}{c}{ Correct } \\
\hline N & $\%$ & N & $\%$ \\
\hline
\end{tabular}

\section{In case a person chokes:}

Only encourage coughing, if the victim is conscious

Lie the victim down

Remove dentures or other foreign objects that may be loose in the mouth

Give back blows if the victim cannot cough

Leave the victim and ask for help

If the victim is unconscious, re-inspect the mouth for foreign objects

Apply the Heimlich maneuver

\section{Regarding the rescuer's safety}

Evaluate security conditions before approaching a victim

There is no risk of contagion in contact with the victim's sweat

The pocket handkerchief is an effective protection to disease transmission in resuscitation procedures

In case of electric shock, immediately grab the victim to keep him/her away from danger

If a victim has ingested pesticide and is not breathing, one should not blow on the mouth

\section{Faced with a child victim:}

Perform a minute of CPR in an unconscious child before asking for help

Performing chest compressions is a correct technique for infants in respiratory arrest

Alternate 15 chest compressions with 2 breaths for infants in cardiac arrest

Chest compressions are performed with two fingers on the inter-nipple midline in infants older than a year

Alternate five chest compressions with two breaths for infants in cardiac arrest

\section{In special situations:}

The rescuer should lie down the victim with severe chest pain and shortness of breath to prevent him/her from getting tired

A victim with violent headache, sudden loss of speech and difficulty in moving a body part must be positioned on his/her side

Before a victim with visible bleeding, it is important to wear gloves, expose the wound and compress the bleeding area with compresses or a scarf

Remove any foreign body from the bleeding wound and place a tourniquet on the limb root, if the wound is on an arm or leg

Before a victim with suspected severe allergic reaction, move him/her away from the possible cause and ask for help immediately - call 112

In intoxicated victims, the toxic name, quantity, time and situation of occurrence are aspects of little importance

In a situation of electrocution, the rescuer must ensure the power source was turned off before approaching the victim

In any victim it is important to prevent hypothermia

In a drowning victim, there should always be suspicion of cervical spine injury

In a pregnant victim, the resuscitation procedures are identical to other victims, but elevating the right hip

\begin{tabular}{|c|c|c|c|}
\hline 827 & 48.3 & 886 & 51.7 \\
\hline 779 & 45.5 & 934 & 54.5 \\
\hline 546 & 31.9 & 1,167 & 68.1 \\
\hline 913 & 53.3 & 800 & 46.7 \\
\hline 695 & 40.6 & 1,018 & 59.4 \\
\hline 908 & 53.0 & 805 & 47.0 \\
\hline 1,148 & 67.0 & 565 & 33.0 \\
\hline 345 & 20.1 & 1,368 & 79.9 \\
\hline 1,288 & 75.2 & 425 & 24.8 \\
\hline 1,126 & 65.7 & 587 & 34.3 \\
\hline 582 & 34.0 & 1,131 & 66.0 \\
\hline 967 & 56.5 & 746 & 43.5 \\
\hline 1,328 & 77.5 & 385 & 22.5 \\
\hline 1,415 & 82.6 & 298 & 17.4 \\
\hline 1,502 & 87.7 & 211 & 12.3 \\
\hline 1,397 & 81.6 & 316 & 18.4 \\
\hline 1,511 & 88.2 & 202 & 11.8 \\
\hline 1,489 & 86.9 & 224 & 13.1 \\
\hline 1,421 & 83.0 & 292 & 17.0 \\
\hline 571 & 33.3 & 1,142 & 66.7 \\
\hline 1,409 & 82.3 & 304 & 17.7 \\
\hline 540 & 31.5 & 1,173 & 68.5 \\
\hline 477 & 27.8 & 1,236 & 72.2 \\
\hline 349 & 20.4 & 1,364 & 79.6 \\
\hline 623 & 36.4 & 1,090 & 63.6 \\
\hline 1,258 & 73.4 & 455 & 26.6 \\
\hline 1,634 & 95.4 & 79 & 4.6 \\
\hline
\end{tabular}

Table 5 - Results of the Student $t$ test application regarding the knowledge level* of the sample on BLS - gender, frequency of some BLS course and performance of BLS - Portugal, 2010-2012.

\begin{tabular}{|c|c|c|c|c|c|c|}
\hline Variables & & $\mathbf{N}$ & Average of correct answers & Standard deviation & $\mathbf{t}$ & $\mathbf{P}$ \\
\hline \multirow{2}{*}{ Gender } & Male & 754 & 27.3 & 12.0 & \multirow{2}{*}{4.521} & \multirow{2}{*}{0.000} \\
\hline & Female & 943 & 24.8 & 11.0 & & \\
\hline \multirow{2}{*}{ Have you attended any BLS course } & Yes & 303 & 35.6 & 10.7 & \multirow{2}{*}{17.481} & \multirow{2}{*}{0.000} \\
\hline & No & 1,398 & 23.8 & 10.6 & & \\
\hline \multirow{2}{*}{ Have you ever had to perform BLS } & Yes & 243 & 31.0 & 11.5 & \multirow{2}{*}{7.627} & \multirow{2}{*}{0.000} \\
\hline & No & 1,425 & 25.0 & 11.3 & & \\
\hline
\end{tabular}

*values may range between 0 and 64 . 


\section{DISCUSSION}

More than half of the study sample was female (55.6\%), a percentage similar to the Portuguese population ${ }^{(14)}$. According to the 2011 census $^{(15)}$, about $47 \%$ of the population is married. Data in this study are different, with a greater number of married subjects (60.7\%). However, data include $13 \%$ of individuals living in common-law marriage, which is different from information in the 2011 census.

According to the census, $15 \%{ }^{(14)}$ of people have higher education, which is much lower than the percentage observed in this study (31.3\%). Approximately $30.2 \%$ of the sample have a profession in the area of administrative personnel and alike, and this value is explained by the selected data collection sites (companies and schools). In the general population, trade, hotels, transports and communications, and other service activities, are the professional activities where more people are employed, approximately $30 \%$ and $29 \%$, respectively ${ }^{(14)}$.

The results of several studies show that the implementation of basic life support measures by the citizen/lay people with training reduces mortality and morbidity rates ${ }^{(7,15-16)}$. Individuals who had cardiopulmonary resuscitation (CPR) of a trained citizen/lay person are four times more likely to survive for 30 days that those in which $\mathrm{CPR}$ was not applied ${ }^{(17)}$.

In the present study, the low percentage $(17.8 \%)$ of people who attended a BLS course is noteworthy. In this regard, several studies have mixed results: in some, the vast majority of spectators of critical events did not have first aid training ${ }^{(7,18)}$, in others, on the other hand, more than half of the sample (54.1\%) had CPR training, and $21.2 \%$ immediately initiated $\mathrm{CPR}^{(19)}$. In another study ${ }^{(11)}$, the authors found that $77.9 \%$ of participants had attended some kind of preparation in the area of first aid, although $61 \%$ had not done any training in the past five years ${ }^{(20)}$.

Among the most frequently cited training locations are the qualified training centers (21.8\%) and the Portuguese Red Cross (23.5\%), different from data found in other studies ${ }^{(16,20-22)}$. In a study conducted through telephone interviews with 7,320 respondents, the most common sources of training in first aid, more specifically in burns, were books (41.7\%) and the internet (32.9\%). In only $9.8 \%$ of cases the respondents resorted to the health authorities and surgery doctors as sources of information/training ${ }^{(23)}$. On the other hand, in a study in Brazil, the authors ${ }^{(16)}$ found that $35.6 \%$ had their training in the drivers' preparation course and $20.6 \%$ had it in the workplace. These differences may be due to the type of sample, place and type of data collection instrument.

Of the 1,668 people participating in the study, 1,425 (85.4\%) never had to perform BLS. Traffic accident was the most reported situation (22.5\%) for those who had already provided assistance, a slightly higher data $(12.2 \%)$ than that found in another study ${ }^{(16)}$.

Citizens have taken several measures in an emergency situation, such as: application of a bandage/dressing ${ }^{(18)}$, positioning the victim ${ }^{(11,18)}$, bleeding control ${ }^{(11,18)}$, ensure safety at accident site ${ }^{(10,16)}$, release of the victim ${ }^{(16)}$, opening the airway ${ }^{(11,18)}$, precautions against hypothermia ${ }^{(16)}$, cardiopulmonary resuscitation ${ }^{(16)}$ and providing tranquility to the victim ${ }^{(11,18)}$.

Taking into account the probability of avoiding $4.5 \%$ of potential prehospital deaths with immediate $\mathrm{BLS}^{(24)}$, and considering the first link in the chain of survival ${ }^{(1)}$, in this study, $47.5 \%$ of participants asked for help by immediately accessing the emergency medical system (dial 112), which is in agreement $(31 \%)$ with results from another study ${ }^{(16)}$.

When asked about who should offer the training, 63.6\% mentioned the National Institute of Medical Emergency. Training is carried out by doctors and nurses in this institution, which is in line with the highlighted information in the literature, stating that it should be done by skilled personnel ${ }^{(7,10,16)}$.

Approximately $95.6 \%$ of the sample showed availability to attend the training, and similar results (94.45\%) were found in the study carried out with students ${ }^{(25)}$. Training must be offered in cultural associations aimed at community groups $(88.4 \%)$ or in the workplace (84.9\%). These options would facilitate adherence to training by avoiding the displacement of participants.

Training in BLS should begin in the student population and before the start of higher education ${ }^{(6)}$. Authors of recent studies ${ }^{(4)}$ showed that even nine-year-old children can perform CPR if properly prepared. Having the training is important and there should be recycling to improve knowledge and confidence of those involved ${ }^{(4,6)}$.

In a quasi-experimental study of students with average age of $21.5 \pm 0.74$ years who received formal training and practice in first aid, the authors ${ }^{(25)}$ found these students had better knowledge than those who had not attended training $(p<0.001)$. Similar results were found by other authors ${ }^{(8)}$ in a study with Danish students (average age of $17.5 \pm 1.2$ years) and students from 13 European countries ${ }^{(26)}$. Some studies have shown that even individuals who had training presented low values of knowledge ${ }^{(25,27)}$ and some said they did not feel prepared ${ }^{(16,26)}$. Still, it is proven that adult training in BLS is effective and necessary ${ }^{(28-29)}$, reinforcing the need for recycling and updating knowledge ${ }^{(7)}$.

Regarding the level of knowledge, as in another study ${ }^{(7)}$, it was found that the studied population had insufficient and some incorrect knowledge. Male respondents who attended a course in BLS and those with experience in BLS showed higher levels of knowledge on BLS, on average. In a study with students, the authors ${ }^{(25)}$ found that women and those who had previous training showed higher level of knowledge on BLS. The rate of correct answers in 64 questions was $25.9 \%$, higher than the $10 \%$ found in another study ${ }^{(16)}$. However, the content and the questions are not similar with those of the present study (degree of difficulty/ different scope).

According to international guidelines ${ }^{(1-2,13)}$, more than $50 \%$ gave wrong answers for the questions related to chest compressions. However, $79.9 \%$ of respondents gave correct answers on the items concerning the safety of rescuer.

When the victim breathes and if not traumatized, 51.4\% gave right answer for the question of the proper placement, 
a higher value than that from another study ${ }^{(14)}$. The victim should be placed in the recovery position to prevent airway obstruction and consequent respiratory arrest ${ }^{(1-2)}$.

When the victim chokes, only $33 \%$ of respondents said the Heimlich maneuver should be performed. Such maneuver should be performed whenever there is serious airway obstruction and the victim is conscious. If choking is mild and the cough is effective, coughing should be encouraged and the person monitored. However, if the person is unconscious and the obstruction is severe, the rescuer should call 112 and begin CPR $^{(1-2)}$.

The area of interventions to the child had the lowest percentage of correct answers, between 22.5\% (faced with the unconscious child, perform CPR for a minute before calling help) and $11.8 \%$ (in an infant in cardiac arrest, five chest compressions should be alternated with two breaths). In infants, chest compressions must follow the compression-ventilation ratio of $15: 2$ (with two rescuers) ${ }^{(1-2)}$.

\section{CONCLUSION}

The results of this study reinforce the need for training laypeople in BLS to reduce mortality and morbidity rates in situations of accident and sudden illness in extrahospital setting. Although there are several courses in the
Portuguese community, both in the classroom and online, some mandatory, it is necessary to introduce the subject in the school curricula of all young people as early as possible. Theoretical and practical training programs should be conducted in schools and workplaces to empower the population in this area, reducing morbidity and mortality due to accidents and emergencies.

Respondents had low levels of knowledge on BLS, evidencing the need and the availability to have the training. Courses should be managed by health professionals, including nurses, maximizing the skills of these professionals in BLS. Despite some difficulties in completing the instrument given its extent, respondents found it useful to realize the knowledge gaps and the importance of attending the training.

We encourage replication of the study in other research scenarios, particularly with children and teachers. In future studies, it would be important to increase the sample size and develop longitudinal studies, after conducting theoretical and practical training, aiming to assess their effectiveness. It would also be interesting to develop documentary analysis to verify the morbidity and mortality of victims of accident or sudden illness rescued or not by lay people with and without training.

\section{RESUMO}

Objetivo: Avaliar o nível de conhecimento e a disponibilidade da população portuguesa para realizar formação sobre Suporte Básico de Vida (SBV) e identificar alguns fatores relacionados ao seu nível de conhecimento sobre SBV. Método: Estudo observacional realizado com 1.700 pessoas que responderam a um questionário composto por dados sociodemográficos e profissionais, formação, interesse na formação e conhecimentos sobre SBV. Resultados: Dos 754 homens e 943 mulheres, apenas 17,8\% (303) frequentou um curso sobre SBV, mas 95,6\% manifestou disponibilidade para realizar a formação. Em média, não apresentaram bons níveis de conhecimentos em suporte básico de vida (acertaram em 25,9 \pm 11,5 dos 64 indicadores). Os inquiridos mais velhos, do sexo masculino, os que efetuaram formação e os que já prestaram SBV acertaram em média mais questões $(\mathrm{p}<0,01)$. Conclusão: Os níveis de conhecimento da população portuguesa são baixos, mas as pessoas estão disponíveis para formação, sendo importante desenvolver cursos de formação e treino para melhorar os seus conhecimentos.

\section{DESCRITORES}

Ressuscitação Cardiopulmonar; Primeiros Socorros; Conhecimento; Educação em Saúde.

\section{RESUMEN}

Objetivo: Evaluar el nivel de conocimiento y la disponibilidad de la población portuguesa para llevar a cabo la formación sobre Soporte Básico de Vida (SBV) e identificar algunos factores relacionados con su nivel de conocimiento acerca del SBV. Método: Estudio observacional realizado con 1.700 personas que respondieron a un cuestionario compuesto de datos sociodemográficos y profesionales, formación, interés en la formación y conocimientos sobre SBV. Resultados: De los 754 hombres y 943 mujeres, solo el 17,8\% (303) asistió a un curso sobre SBV, pero el 95,6\% manifestó disponibilidad para realizar la formación. En promedio, no presentaron buenos niveles de conocimientos en soporte básico de vida (contestaron bien 25,9 $\pm 11,5$ de los 64 indicadores). Los respondedores mayores, del sexo masculino, los que llevaron a cabo la formación y los que ya prestaron SBV contestaron bien, en promedio, más cuestiones ( $\mathrm{p}<0,01$ ). Conclusión: Los niveles de conocimiento de la población portuguesa son bajos, pero las personas están disponibles para la formación, por lo que es importante desarrollar cursos de formación y entrenamiento a fin de mejorar sus conocimientos.

\section{DESCRIPTORES}

Resucitación Cardiopulmonar; Primeros Auxilios; Conocimiento; Educación en Salud.

\section{REFERENCES}

1. Portugal. Instituto Nacional de Emergência Médica. Manual de suporte avançado de vida. $2^{\text {a }}$ ed. Lisboa: INEM; 2011.

2. European Resuscitation Council. Guidelines for Resuscitation [Internet]. 2010 [cited 2014 Apr 10]. Available from: http://www.cprguidelines.eu/2010/

3. Portugal. Instituto Nacional de Estatística. Estatísticas dos transportes. Lisboa: INE; 2011. 
4. Meissner TM, Kloppe G, Hanefeld C. Basic life support skills of high school students before and after cardiopulmonary resuscitation training: a longitudinal investigation. Scand J Trauma Resusc Emerg Med [Internet]. 2012 [cited 2014 Apr 10];20:31. Available from: http:// www.ncbi.nlm.nih.gov/pmc/articles/PMC3353161/

5. Lešnik D, Lešnik D, Golub J, Križmarić M, Mally S, Grmec S. Impact of additional module training on the level of basic life support knowledge of first year students at the University of Maribor. Int J Emerg Med [Internet]. 2011 [cited 2014 Apr 10];4:16. Available from: http:// www.ncbi.nlm.nih.gov/pmc/articles/PMC3095545/

6. Miró Andreu O, Escalada Roing X, Jiménez-Fábrega X, Díaz Miranda N, Sanclemente G, Villena O, et al. Programa de Reanimación Cardiopulmonar Orientado a Centros de Enseñanza Secundaria (PROCES): conclusiones tras 5 años de experiencia. Rev Soc Esp Med Urgencias Emerg. 2008;20(4):229-36.

7. Pergola A M, Araujo IEM. Laypeople and basic life support. Rev Esc Enferm USP [Internet]. 2009 [cited 2014 Apr 10];43(2):335-42. Available from: http://www.scielo.br/pdf/reeusp/v43n2/en_a12v43n2.pdf

8. Marton J, Pandúr A, Pék E, Deutsch K, Bánfai B, Radnai B, et al. Knowledge about basic life support in European students. Orv Hetil. 2014;25;155(21):833-7.

9. Hall A, Wotton K, Hutton A. Bystander experiences at and after a motor vehicle accident: a review of the literature. Austr J Paramed [Internet]. 2013 [cited 2014 Mar 12];10(4). Available from: http://ro.ecu.edu.au/jephc/vol10/iss4/2

10. Mori S, Whitaker IY, Marin HF. Evaluation of an educational website on first aid. Rev Esc Enferm USP [Internet]. 2013 [cited 2014 Aug 10];47(4):950-7. Available from: http://www.scielo.br/pdf/reeusp/v47n4/en_0080-6234-reeusp-47-4-0950.pdf

11. Arbon P, Hayes J. First aid and harm minimization for victims of road trauma: a population study. Final Report June 2007 [Internet]. Adelaide, Australia: Flinders University; 2007 [cited 2014 Apr 24). Available from: http://clicktosave.com.au/wp-content/uploads/2013/06/ Australian_Population_Study_on_victims_of_Road_Trauma1.pdf

12. Liu KY, Haukoos JS, Sasson C. Availability and quality of cardiopulmonary resuscitation information for Spanish-speaking population on the Internet. Resuscitation. 2014;85(1):131-7.

13. American Heart Association. 2010 Guidelines for Cardiopulmonary Resuscitation and Emergency Cardiovascular Care Science. Circulation [Internet]. 2010 [cited 2014 Aug 10];122 Suppl 3:S639-946. Available from: http://www.counselling-care.it/pdf/pdf_ps/2010-ahaguidelines.pdf

14. Portugal. Instituto Nacional de Estatística. Censos 2011. XV Recenseamento Geral da População. V Recenseamento Geral da Habitação. Resultados definitivos. Lisboa: INE; 2012.

15. Murad MK, Husum H. Trained lay first-helpers reduce trauma mortality: a controlled study of rural trauma in Iraq. Prehosp Disaster Med. 2010;25(6):533-9.

16. Pergola AM, Araujo IEM. The layperson in emergency situations. Rev Esc Enferm USP [Internet]. 2008 [cited 2014 Aug 10];42(4):769-76. Available from: http://www.scielo.br/pdf/reeusp/v42n4/en_v42n4a20.pdf

17. Wissenberg M, Lippert FK, Folke F, Weeke P, Hansen CM, Christensen EF, et al. Association of national initiatives to improve cardiac arrest management with rates of bystander intervention and patient survival after out-of-hospital cardiac arrest. JAMA. 2013;310(13):1377-84.

18. Mauritz W, Pelinka LE, Kaff A, Segall B, Fridrich P. First aid measures provided by bystanders at the accident site: a prospective epidemiological study in the area of Vienna. Wien Klin Wochenschr. 2003;115(19-20):698-704.

19. Swor R, Khan I, Domeier R, Domeier RM. CPR training and CPR performance: do CPR-trained bystanders perform CPR? Acad Emerg Med. 2006;13(6):596-601.

20. Larsson EM, Martensson NL, Alexanderson KA. First-aid training and bystander actions at traffic crashes: a population study. Prehosp Disaster Med. 2002,17(3):134-41.

21. Jones CM, Owen A, Thorne CJ. Comparison of the quality of basic life support provided by rescuers trained using the 2005 or 2010 ERC guidelines. Scand J Trauma Resusc Emerg Med. 2012;20:53.

22. Akpek EA, Kayhan Z. Knowledge of basic life support: a pilot study of the Turkish population by Baskent University in Ankara. Resuscitation. 2003;58(2):187-92.

23. Harvey LA, Bar ML, Poulos RG, Finch CF, Sherker S, Harvey JG. A population- based survey of knowledge of burns in New South Wales. Med J Aust. 2011;195(8):465-8.

24. Ashour A, Cameron P, Bernard S, Fitzgerald M, Smith K, Walker T. Could bystander first-aid prevent trauma deaths at the scene of injury. Emerg Med Australas. 2007; 19(2):163-8.

25. Khan A, Shaikh S, Shuaib F, Sattar A, Samani SA, Shabbir Q, et al. Knowledge attitude and practices of undergraduate students regarding first aid measures. J Pak Med Assoc. 2010;60(1):68-72.

26. Aaberg AMR, Larsen CEB, Rasmussen BS, Hansen CM, Larsen JM. Basic life support knowledge, self-reported skills and fears in Danish high school students and effect of a single 45 -min training session run by junior doctors; a prospective cohort study. Scand J Trauma Resusc Emerg Med. 2014, 22:24.

27. Cheung B, Ho C, Kou O, Kuong EE, Lai KW, Leow PL, et al. Knowledge of cardiopulmonary resuscitation among the public in Hong Kong: telephone questionnaire survey'. Hong Kong Med J. 2003; 9(5):323-8.

28. Janisha KP, Priya V, Fermina J. Effectiveness of planned teaching programme on knowledge regarding basic life support among young adults. Int J Nurs Educ. 2012;4 (1):28.

29. Miyadahira AMK, Quilici AP, Martins CC, Araújo GL, Pelliciotti JSS. Cardiopulmonary resuscitation with semi-automated external defibrillator: assessment of the teaching-learning process. Rev Esc Enferm USP [Internet]. 2008 [cited 2014 Aug 10];42(3):532-8. Available from: http://www.scielo.br/pdf/reeusp/v42n3/en_v42n3a16.pdf 